Pamiętnik Literacki 2014, 3, s. 129-143
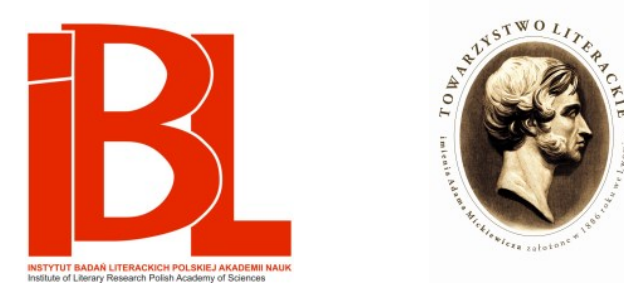

O kilku ideach ważnych dla rozumienia prozy Leopolda Buczkowskiego

Bogdan Owczarek 


\section{O KILKU IDEACH WAŻNYCH DLA ROZUMIENIA PROZY LEOPOLDA BUCZKOWSKIEGO}

Interesującym zjawiskiem w recepcji twórczości Leopolda Buczkowskiego jest to, że stopniowemu ubywaniu jej odbiorców towarzyszy stałe przybywanie nielicznych, co prawda, ale wciąż nowych czytelników i badaczy ${ }^{1}$. Świadczy to o trudnej, być może, do wyjaśnienia, lecz niewątpliwie istniejącej sile przyciagania i oddziaływania tej prozy - niełatwej przecież i przynoszącej oddanym czytelnikom wiele rozmaitych rozterek i niekiedy nawet poczucie bezradności przy próbach jej zrozumienia. Chyba warto raz jeszcze zastanowić się, na czym ta siła przyciagania polega i dlaczego czytanie Buczkowskiego jest zajęciem ambarasującym.

Powstanie Wertepów dzieli od wydania Kamienia w pieluszkach ponad 40 lat, które obejmują całą twórczość artystyczną pisarza. Wolno się spodziewać, że w tym czasie zaszły pewne zmiany w ideach w niej zawartych. Nie myślę, żeby było trafne spostrzeżenie, które kiedyś sformułowałem: „W lekturze utworów Buczkowskiego powstaje wrażenie [...], iż w zasadzie od Czarnego potoku po Kamień w pieluszkach autor pisze jakby wciąż tę samą książkę"2. Jeśli przyjrzeć się utworom pisarza bardziej starannie, to dostrzeże się, iż niektóre $z$ nich tworzą różne skupienia, inne są osobnymi formacjami. Przede wszystkim debiutancki tom Wertepy (1937) - jak się wyraził Kazimierz Wyka: „ksiażka o wsi” ${ }^{3}$ - stanowi rzecz stylistycznie i tematycznie odrębną, nie mającą kontynuacji w dalszej twórczości pisarza. Czarny potok (1954), najbardziej znane i uznane dzieło Buczkowskiego, bliski jest Doryckiemu krużgankowi (1957). O ile Wertepy można uważać za tekst w pełni zakończony pod względem tematycznym i kompozycyjnym, o tyle w Czarnym potoku i Doryckim krużganku fabuła ulega już wyraźnym komplikacjom, pojawiają się wątki równoległe, utwory te nie mają kompozycyjnego zamknięcia. O ich podobieństwie decyduje zbliżona tematyka - mroczna wędrówka i chaotyczne potyczki grupy samoobrony podczas drugiej wojny światowej i okupacji niemieckiej na polskich Kresach.

1 Zob. S. Bu ryła, Prawda mitu i literatury. O pisarstwie Tadeusza Borowskiego i Leopolda Buczkowskiego. Kraków 2003. - A. Karpowi cz, Kolaż. Awangardowy gest kreacji. Themerson, Buczkowski, Białoszewski. Warszawa 2007. - ...zima bywa się pisarzem... O Leopoldzie Buczkowskim. Red. S. Buryła, A. Karpowicz, R. Sioma. Kraków 2008.

2 B. Ow czar e k, Proza Leopolda Buczkowskiego. „Miesięcznik Literacki” 1982, nr 10, s. 73.

3 K. Wy ka, Pogranicze powieści. Wyd. 2, poszerz. Warszawa 1974, s. 302-310. 
Opowiadania z tomu Młody poeta w zamku (1959) oraz powieść Pierwsza świetność (1966) to, moim zdaniem, teksty przejściowe w twórczości pisarza, $z$ jednej bowiem strony, utrzymują one charakterystyczną dla utworów poprzednich problematykę wojenną i przygnębiającą atmosferę Holocaustu, $z$ drugiej - pojawiają się już w nich elementy nowatorstwa formalnego, próby rozluźnienia fabuły i niefabularnej organizacji tematu. W końcu utwory późniejsze, poczynając od Urody na czasie (1970), przez Kapiele $w$ Lucca (1974) i Oficera na nieszporach (1975) po Kamień $w$ pieluszkach (1978), stanowia grupę tekstów dojrzałych, określających najpełniej oblicze pisarstwa Buczkowskiego; każdy z nich ma właściwą dla siebie i odmienną od innych fakturę oraz styl, charakteryzujące najlepiej, najbardziej precyzyjnie wszystkie cechy tej prozy, które chciałbym tutaj najobszerniej zaprezentować.

Najprościej można by powiedzieć, że prawie wszystkie utwory Buczkowskiego w jakiś sposób są poświęcone wydarzeniom wojennym, tyle że w różnych utworach inaczej je pisarz przedstawia i inaczej się do nich odnosi. Jak wskazuja prace literaturoznawcze ${ }^{4}$, charakterystyczny dla tego pisarstwa obraz wojny ustalił Czarny potok: to wizja okrucieństwa i zagłady mieszkańców Szabasowej, przemocy w stosunkach ludzkich na terenie Kresów, okupowanych przez Niemców, mroczna atmosfera wędrówki i walki niewielkiego oddziału samoobrony z niemieckim okupantem i ukraińską hilfspolicją, zasygnalizowana już pierwszymi słowami powieści:

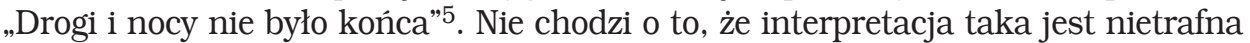
w przypadku Czarnego potoku, ale o to, że uważa się ją za reprezentatywna dla całej twórczości pisarza. Tymczasem jego stosunek do wojny stopniowo się zmieniał. Pod tym względem przełomowe są dwa utwory - Pierwsza świetność i Uroda na czasie.

Pierwsza świetność jako rdzeń przedstawienia wojny obiera sobie dwa właściwie watki zdarzeniowe: zagładę Szmulek i rozstrzelanie kilkunastu żydowskich dziewcząt - obraz powracający kilkakrotnie w różnych konfiguracjach - oraz partyzancki zamach na majora ukraińskiego batalionu ochotniczego Badadio, który został zabity w wychodku. Na tle owych zdarzeń toczą się nieustanne roztrząsania na temat warunków, okoliczności i komplikacji ich postrzegania oraz niewystarczalności i nieadekwatności relacji o nich. Towarzyszą tym rozważaniom dwa rodzaje dyskursu o niezidentyfikowanej podmiotowości - bezosobowy dyskurs analityczny, stylizowany często na wykład lub analizę naukową, i anonimowy dyskurs narracyjny, przybierający postać refrenu, opowiadający o procesie śledztwa i pisania protokółu, zaczynający utwór: „I dalej zapytany, czy rzeczywiście tak się nazywa, czy tylko przybrał sobie takie nazwisko, oświadczył, że tak się nazywa [...]"6. Za sprawą Stanisława Barańczaka, który zinterpretował ten typ dyskursu jako „stylizację na protokół śledztwa"7, można było przyjąć, że tym samym śledztwo stało się sposobem wprowadzenia w obręb tekstu specyficznej „sytuacji komunikacyjnej”.

4 Zob. T. Błażej ews ki, Przemoc świata. Pisarstwo Leopolda Buczkowskiego. Łódź 1991. - B uryła, op. cit.

5 L. Buczkows ki, Czarny potok. Wyd. 4. Warszawa 1971, s. 7.

6 L. Buczkows ki, Pierwsza świetność. Wyd. 2. Kraków 1978, s. 5.

7 S. Barańczak, Krwawy karnawał. „Teksty” 1973, nr 4, s. 56.

$8 \quad$ Ibidem, s. 58. 
Chciałbym tylko dodać, iż jeden $z$ kolejnych fragmentów powracającego refrenu o zapytanym właściwie demaskuje możliwą ramę komunikacyjną i - co za tym idzie - cały wzorzec śledztwa.

Zapytany, czy rzeczywiście tak się nazywa, czy tylko przybrał sobie takie nazwisko, oświadczył, że tak się nie nazywa, lecz został nazwany przez korespondenta w miłej pogawędce, być może dlatego, ażeby stwierdzić na nowo w formie inwertowanej wszystko to, co zostało stwierdzone dawniej w salonowych rakietach Oskara Wilde'a ${ }^{9}$.

Przełomowość Pierwszej świetności polega na tym, że Buczkowski opowiadając o okrucieństwie wojny jednocześnie wypróbowuje różne formy przekazywania relacji o niej. W utworze utrwala się swoista epistemologia wielorakiego widzenia, o której narrator mówi wprost gdzie indziej:

Oto przykład potrójnego widzenia: widzenie, jakie miał zwiadowca, gdy padł obserwator rażony odłamkiem, od której to chwili nie wymówił był ani słowa; widzenie ordynansa, dotyczące autentyczności faktów, oraz widzenie rzeczywistości, która się tworzy poprzez rzeczywistość zanikającą ${ }^{10}$.

Pisarz korzystał z tej epistemologii już wcześniej. Jest ona widoczna w Czarnym potoku, kiedy różni ludzie są charakteryzowani przez innych, kiedy obraz postaci narzucony przez tzw. opinię zbiorową składa się ze sprzecznych relacji osób postronnych; ujawniony tu krytycyzm oraz wątpliwości pozwalaja, zgodnie z epistemologia wielorakiego widzenia, spojrzeć na Pierwsza świetność jako na utwór podważający pełnię przedstawienia obrazu wojny - ze względu na cząstkowość widzenia zaangażowanych $\mathrm{w}$ obserwacje oraz na opowiadanie $\mathrm{z}$ wielu perspektyw i na ograniczoność środków przekazu: relacji obserwatorów, protokółów, literatury i filmu (w powieści pojawia się również wątek kręcenia filmu według scenariusza podobnego do Pierwszej świetności).

Odmienność widzenia spraw wojny można dostrzec także w Urodzie na czasie. Wynika ona $z$ konstrukcji innej niż w utworach poprzednich. Nie ma tu już narracji o zdarzeniach wojennych, tekst zbudowany jest na modelu konwersacyjnym, anonimowe postaci (czasami sa to postaci historyczne, np. pani Walewska lub Napoleon Bonaparte) rozmawiają na różne tematy dotyczące życia i kultury, m.in. na temat wojska, wojny i narodowej historii. Rozmowy wzajemnie przenikaja się, granice między kwestiami są rozmyte. Brakuje wyraźnych sygnałów składniowych lub tematycznych, które by jednoznacznie odgraniczały prowadzone rozmowy. W konwersacjach pojawiają się niekiedy krótsze lub dłuższe opowieści. Model konwersacyjny budowy tekstu Urody na czasie utrwala wydobyta w Pierwszej świetności epistemologię wielorakiego widzenia, albowiem nie ma w utworze ani jednolitego tematu, ani wyraźnie zarysowanych postaci. Przede wszystkim uwidoczniona zostaje sama konwersacja.

Pojawiają się także nowe aspekty wojny. W Pierwszej świetności narracja dotyczyła konkretnych wydarzeń drugiej wojny światowej lub niewielkich epizodów pierwszej wojny. W Urodzie na czasie o wypadkach wojennych mówi się ogólnie, wspomina się o wojnach napoleońskich i pierwszej wojnie światowej, rozmowa 
toczy się także w telewizji i dotyczy współczesności, tj. lat sześćdziesiątych XX wieku. Wojnę w Urodzie na czasie traktuje się jako kataklizm i bezrozumny żywioł, opanowujący ludzkie umysły i świadomość grup ludzkich na całym świecie. Jedna $\mathrm{z}$ anonimowych postaci mówi:

Kiedy zaczynamy dźwigać rolnictwo, ulepszać inwentarz, wydzierać się z rąk lichwiarzy i samodzielniej oddychać - klęski publiczne przychodzą i niweczą wszystkie usiłowania.

A wojna trzydziestoletnia i siedmioletnia, a stotysięczny korpus Napoleona, a nieustająca prawie zaraza bydła? ${ }^{11}$

Dla takiej konwersacyjnej, mozaikowej konstrukcji tekstu charakterystyczne są częste zderzenia różnych stylów, tematów i aspektów wypowiedzi. Dotyczy to także tematu wojny:

A wojna zbankrutowała.

Myślałem, że coś innego. Ale dlaczego, jaki powód? Czyż w pięć miesięcy po zamążpójściu urodzić syna - to bankructwo? ${ }^{12}$

W Urodzie na czasie pojawia się nadto po raz pierwszy figura dezertera, która zdominuje następne utwory: „Nie rób teatru. Zdezerterowałem. Cha, cha. [...] Wierz mi, że bez bólu opuściłem armię na zawsze"13. Trafniejsza niż potoczne opinie wydaje mi się uwaga Andrzeja Falkiewicza o stosunku Buczkowskiego do wojny:

Wcale nie zamierzam negować roli II wojny światowej w twórczości Buczkowskiego, doświadczenia czasów zagłady jako straszliwej inicjacji jego sztuki - przeciwnie, jestem skłonny przyznać, że wojna opanowała bez reszty to dzieło. I właśnie dlatego, że opanowała bez reszty, wojna stała się w twórczości Buczkowskiego hipostazą czasoprzestrzeni, hipostazą Bytu ${ }^{14}$.

Mógłbym tylko dodać, że jeśli w Pierwszej świetności autor przedstawia zdarzenia konkretnej wojny, to w Urodzie na czasie odnosi się tylko do pojęcia wojny. Dokonuje się pomiędzy tymi utworami decydująca i znacząca zmiana. We wcześniejszych tekstach Buczkowski jeszcze opowiada o wojnie, od Urody na czasie do Kamienia $w$ pieluszkach już nam jedynie przekazuje komunikat o zjawisku wojny.

Chciałbym tu wrócić do wspomnianego wcześniej zabiegu z d e r z e n i a różnych stylów, tematów i sensów przy wymianie wypowiedzi i narastaniu tekstu Urody na czasie. Jest to zabieg charakterystyczny dla konstrukcji dojrzałych utworów Buczkowskiego, ujawniajacy, moim zdaniem, wiele wariacyjnej zręczności pisarza. Oto kilka przykładów: „Ja doskonale rozumiem. Ale wojna to nie przebieranie jagód na pierogi. Przecież słyszycie, że nawet wiewiórka nie cmoka”; „Poszła ku werandzie, wróciła po chusteczkę, rozsypała papierosy. Pozostawiając papierosy na podłodze, pobiegła i o mało nie przewróciła się na psie”; „A wiecie, dlaczego Szopen uciekł stamtad [tj. $z$ Nietrzeby - B. O.] - bo mu na koncercie dwie baby zjadły w zachwycie rękawiczki, a że tego było za mało, więc się wzięły do spodni i łydek" 15 .

L. B u c zk ow ski, Uroda na czasie. Wyd. 1. Warszawa 1970, s. 173-174.

Ibidem, s. 156.

Ibidem, s. 105.

A. F a l ki e w i c z, Dezercja Leopolda Buczkowskiego. W: Fragmenty o polskiej literaturze. Warszawa 1982, s. 151-152.

Bu czkowski, Uroda na czasie, s. 202, 106, 155. 
Wszystkie te cytaty prezentują językowe zd e r z e n i e sytuacji, wyrażeń i sensów, ujawniaja określone zaskoczenie, nawet swoisty bezsens, albowiem zwykle mowa nie łączy ze sobą słów w taki sposób, by powstały efekty komiczne, parodystyczne, ewentualnie - irytujące lub bulwersujace. Mamy do czynienia w tych zderzeniach zdań i wyrazów z chwytem podobnym do dezautomatyzacji, o którym rosyjscy formaliści mówili, że „wyzwala rzeczy $z$ automatyzmu percepcji” ${ }^{16}$. Zjawisko dezautomatyzacji posłużyło także Bertoltowi Brechtowi w koncepcji teatru epickiego do ukształtowania - fundamentalnego dla jego praktyki - efektu obcości (Verfremdungseffekt):

Mamy na myśli, mówiąc pokrótce, pewną technikę, dzięki której można nadać przedstawionym zdarzeniom międzyludzkim znamię czegoś zaskakującego, wymagającego wyjaśnienia, czegoś nieoczywistego, czegoś, co nie jest w prosty sposób naturalne ${ }^{17}$.

Dzięki zręcznie zastosowanym efektom obcości w dojrzałych tekstach swoich późnych utworów Buczkowski, komponując te zdumiewające sekwencje zdań, przemieszcza uwage czytelnika $z$ określonych zdarzeń historii Polski lub $z$ odpowiednich sytuacji $z$ wojen europejskich na nadzwyczajną ważność języka, który staje się widocznym i decydującym narzędziem społecznym w codziennej konwersacji, jakim posługujemy się dla kształtowania naszych umysłów oraz uczuć. W Urodzie na czasie chyba po raz pierwszy z taką determinacją i moca wyrażono potrzebę, a nawet konieczność odnowienia języka wypowiedzi społecznej o życiu, wojnie i sztuce, odnowienia języka samej komunikacji literackiej.

Specyfikę prozy Leopolda Buczkowskiego badacze literatury najczęściej tłumaczą przeżyciem przez pisarza traumy drugiej wojny światowej i okupacji niemiec$\mathrm{kiej}^{18}$. Trudno byłoby obalić takie stwierdzenie, zarazem niełatwo jest je jednoznacznie potwierdzić. Albowiem trauma dobrze wyjaśnia przemianę twórczości pisarza, ale wcale nie tłumaczy, dlaczego przybrała ona taką, a nie inną postać. Pytania o formę i sens dojrzałych utworów Buczkowskiego uważam za jedne $z$ trudniejszych kwestii w historii polskiej literatury XX wieku.

\section{2}

Innym podstawowym problemem, $z$ jakim spotkali się badacze prozy Buczkowskiego, było zagadnienie niespójności jego utworów, uznawane od początku za główną przyczynę ich niezrozumiałości ${ }^{19}$ i wyróżniającą cechę jego pisarstwa. Najpoważniejsza praca z tego zakresu była książka Marii Indyk Granice spójności narracji. Proza Leopolda Buczkowskiego. Duża kompetencja literaturoznawcza autorki, jej wrażliwość i wyczucie formy pisarstwa Buczkowskiego przyczyniły się, moim zda-

W. Szkłow s ki, Sztuka jako chwyt. W zb.: Teoria badań literackich za granica. Antologia. Wybór, rozprawa wstępna, komentarz S. Skwarczyńska. T. 2, cz. 3. Kraków 1986, s. 17 (przeł. R. Łużny).

B. Bre c ht, Wartość mosiądzu. Wybór, układ, noty W. He ch t. Warszawa 1975, s. 62.

- B u rył a, op. cit., s. 86. - D. S k r a b e k, Leopold Buczkowski: traumatyczna tkanka prozy. W zb.: ...zima bywa się pisarzem..., s. 111.

Zob. A. S and a u e r, Pod czy ponad? W: Zebrane pisma krytyczne. T. 3. Warszawa 1981, s. 112. 
niem, do właściwego postawienia problemu. Badaczka wychodzi w zasadzie od dwóch założeń: a) „każdy tekst jest spójny”, b) „żaden tekst nie tłumaczy się sam przez siebie" 20 . Znaczenie jej książki polegało na odwróceniu dotychczasowego problemu i wyjaśnieniu, że teksty autora Czarnego potoku są w istocie spójne jeśli uwzględnimy bardziej rozbudowane kryteria i konteksty czytania literatury: kulturowe i kognitywne. Dla wielu badaczy pisarstwa Buczkowskiego problemem nie była odtąd niespójność jego utworów, ale odnalezienie zasady ich spójności. Historii zmagań literaturoznawców z tą interpretacją i wyjaśnieniem owej zasady poświęcił cenny artykuł Arkadiusz Kalin ${ }^{21}$.

Drugi nurt badań nad prozą autora Urody na czasie, który pośrednio wiązał się z zagadnieniem spójności jego utworów, to próby ukazania sylwicznego, wielogatunkowego charakteru tych tekstów na tle ogólnego - literackiego i kulturowego - podłoża rozwoju prozy współczesnej. Inicjatorem takiego projektu był Ryszard $\mathrm{Nycz}^{22}$. Skierowanie uwagi badaczy na sylwiczną i centonową budowę tekstów współczesnej polskiej prozy literackiej, a w następstwie związanie utworów Buczkowskiego $z$ techniką kompozycji kolażowej stanowiło udaną i owocną próbę poszerzenia kontekstu teoretycznego oraz artystycznego dla studiów nad spójnością i kompozycja jego prozy. Wszystkie analizy czy rozpoznania pozwalaja inaczej spojrzeć na historyczne już opinie badaczy i recenzentów pisarstwa Buczkowskiego oraz ponownie rozpatrzyć ich negatywne spostrzeżenia. Mam na myśli przede wszystkim krytyczną opinię Jana Błońskiego z okazji wydania Pierwszej świetności: „Nie ma już opowieści tam, gdzie do chaosu opowiadanych wydarzeń dodał autor chaos samej funkcji opowiadania"23. Otóż, paradoksalnie, ta negatywna opinia krytyka naprowadza nas na bardzo ważną diagnozę twórczości Buczkowskiego. Pisarz rezygnuje z funkcji narracji w swoich późniejszych dziełach. Jest to widoczne już w Pierwszej świetności, a - jak wspomniałem - dominuje właśnie w kolejnych tekstach. Buczkowski rezygnuje przede wszystkim z głównego narratora, zwykle zapewniającego spójność wszelkim utworom narracyjnym; jego nieobecność dostrzegli zarówno Maria Indyk, która posługuje się w analizach prozy Buczkowskiego pojęciem narratora-redaktora, jak i Tadeusz Błażejewski, który wspomina o autorze-kompilatorze ${ }^{24}$. Pisarz redukuje funkcję opowiadania w swoich utworach, poczynając od Pierwszej świetności, a na rozproszonych i nieciagłych mikroopowieściach kończąc. Zdaje się to potwierdzać opinia Indyk o przytoczeniowym, cytatowym charakterze budowy tekstów Buczkowskiego ${ }^{25}$.

Na pytanie: czy Buczkowski opowiada? - sformułowane w moich ostatnich pracach o prozie pisarza - nie udzieliłem jasnej odpowiedzi ${ }^{26}$. Obecnie jestem skłonny twierdzić, że pisarstwo Buczkowskiego właściwie od Pierwszej świetności

Kolekcje, obiekty, symulakra... Red. nauk. H. Gosk, A. Zieniewicz. Warszawa 2007; Próba rekonstrukcji poetyki Leopolda Buczkowskiego. W zb.: ...zima bywa się pisarzem...

M. In dy k, Granice spójności narracji. Proza Leopolda Buczkowskiego. Wrocław 1987, s. 5, 23.

A. Kali n, Problem spójności prozy Leopolda Buczkowskiego. W zb.: ...zima bywa się pisarzem...

Zob. R. Ny c z: Sylwy wspótczesne. Wyd. 2. Kraków 1996; Tekstowy świat.

J. Błoń s ki, Bezdroże. „Życie Literackie” 1967, nr 42.

In d y k, op. cit., s. 45. - Błażej ew s ki, op. cit., s. 121.

In d y k, op. cit., s. 54-55, 106-107.

B. O w c zar e k: Czy Leopold Buczkowski opowiada. W zb.: Narracje po końcu (wielkich) narracji. 
to nieustanne poszukiwanie i praktykowanie n i e n a r r a c y j n e g o sposobu komponowania tekstów literackich, z którego wynikają właśnie czytelnicze problemy ze spójnością i niejednorodnością jego utworów. Opinie Buczkowskiego w rodzaju:

W typowym pisaniu narracyjnym: on ją poznał, w pierwszym rozdziale spotykają się i deszcz im przeszkodził... Teraz z zaciekawieniem - drugi rozdział: piękna pogoda itd. Znowu się spotykają i to się tak ciagnie. Raz deszcz przeszkodził, raz mama przeszkodziła. Albo on poszedł do wojska, a ona do niego pisała... ${ }^{27}$

- które odnoszono raczej do jego poglądów na poetykę romansu, interpretowałbym właśnie w planie teoretycznym i polemicznym jako świadome odrzucenie narracji we własnym pisarstwie. Rezygnacji w prozie $z$ funkcji głównego narratora i jego punktu widzenia, jednoczącego rozbieżne widzenie rzeczy, nie wiązałbym $z$ konceptem „śmierci autora” 28 , a redukcji opowiadania do mikroopowieści nie łączyłbym z kryzysem metanarracji w kulturze europejskiej ${ }^{29}$.

Realizacja projektu nienarracyjnego komponowania dzieł literackich w prozie Buczkowskiego ma także znaczenie teoretyczne. Na podstawie tekstowej praktyki tego autora da się zrekonstruować model kształtowanej koncepcji utworu, jaka legła u podstaw jego późnego pisarstwa. Można ją, moim zdaniem, zestawić i porównać z literacką praktyką Fiodora Dostojewskiego, która przedstawił Michaił Bachtin jako polifoniczną koncepcję tekstu (w książce Problemy poetyki Dostojewskiego i w rozprawie Problem tekstu $w$ lingwistyce, filologii i innych naukach humanistycznych ${ }^{30}$ ), a która posłuży mi dalej za punkt odniesienia. Artykuł Bachtina od początku reaktywuje rozumienie tekstu jako w y p o w i e d zi i - mają o niej stanowić jej identyfikowalne granice. Warunkiem wypowiedzi jest jej całościowość, która określa ją jako wypowiedź podmiotu i organizuje wszelkie jej dialogowe związki - zarówno wewnętrzne, jak i zewnętrzne - między różnymi wypowiedziami ${ }^{32}$. Tymczasem jedna z notorycznych cech kompozycji tekstu w prozie Buczkowskiego jest trudność lub wręcz niemożliwość utożsamienia podmiotu mówiąc e g o i granic wypowiedzi. Pisze o tym np. Indyk przy analizie Pierwszej świetności:

trudność nie polega na gramatycznej zmianie osób wewnątrz zdania, która pełni rolę sygnału wskazującego na mowę pozornie zależną, ale na totalnym zachwianiu ufności w identyczność podmiotu wypowiadającego zdanie, które może się okazać zlepkiem, kontaminacją różnych części, mimo że pozornie wszystko jest w porządku, zasady gramatyczne są nienaruszone, a zdania składają się w logiczną całość33.

Według Bachtina związki dialogowe nie mogą więc łączyć części lub członów

L. Bu c zkow s ki, Dialog żywy. W: Wszystko jest dialogiem. Warszawa 1984, s. 14.

Zob. Skrabek, op. cit., s. 117.

Zob. J.-F. Ly o tard, Kondycja ponowoczesna. Raport o stanie wiedzy. Przeł. M. Kow als ka, J. Migasiński. Warszawa 1997.

M. Ba chtin: Problemy poetyki Dostojewskiego. Przeł. N. Modzelews ka. Warszawa 1970; Problem tekstu $w$ lingwistyce, filologii i innych naukach humanistycznych. W: Estetyka twórczości słownej. Przeł. D. Uli cka. Oprac. przekładu, wstęp E. C za plej ew i c z. Warszawa 1986.

B a c h t i n, Problem tekstu w lingwistyce, filologii i innych naukach humanistycznych, s. 404-405, 415.

Zob. ibidem, s. 423.

In d y k, op. cit., s. 56. 
całości wypowiedzeniowej ${ }^{34}$. Tymczasem w późnych utworach Buczkowskiego jest stała praktyką łączenie syntaktyczne słów i zdań zderzające ich literalny sens w ramach tej samej formacji, co wywołuje dialogowy, polemiczny lub ironiczny efekt. Przytoczyłem wcześniej z Urody na czasie zdanie o Szopenie, które zresztą zbulwersowało niektórych badaczy prozy Buczkowskiego ${ }^{35}$ : „A wiecie, dlaczego Szopen uciekł stamtąd - bo mu na koncercie dwie baby zjadły w zachwycie rękawiczki [...]”. Podobne zdania można znaleźć w innych utworach pisarza, np. „Dziś rano, kochane dzieci, widzicie między sobą nowych strzelców, którzy dopiero pierwszy raz będą strzelać do ludzi”"36.

Można teraz zrozumieć, że tekst komponowany przez Buczkowskiego nie jest budowany na modelu wypowiedzi, która ukazuje podmiot mówiący i swoje własne granice. W prozie tej, jak ustaliła Indyk, sa jedynie przytoczenia i cytaty wypowiedzi ${ }^{37}$, czyli teksty pisane bez wprowadzania mówiących podmiotów. Jest to p r o za nienarracyjna, konstruowana na innej zasadzie, gdzie nie ma narratora czy postaci w zwykłym sensie, albowiem nie opowiada się w niej anegdot ani historii, ani biografii bohaterów. Mówiąc jeszcze inaczej, autor takiej prozy nie op ow iada, nie przedstawia mówiących postaci w otaczającym ich świecie. $Z$ różnych tekstów-cytatów komponuje większe całości o nieustalonych granicach. Proces kształtowania utworu i komunikacji z publicznością przesuwa się z poziomu narracji na poziom kompozycji.

W prozie realistycznej obraz autora, jak sugeruje Bachtin ${ }^{38}$, jest często uprzedmiotowiony w wypowiedziach narratora lub opowiadajacych postaci. Wskazuje to na inny jeszcze problem poetyki Buczkowskiego, uprzedmiotowienie wypowiedzi jest u niego p odwó j n e: wypowiedzi są cytowane i przytaczane, czyli uprzedmiotowienie wypowiedzi dokonuje się zamiast przedstawiania osób. W prozie Buczkowskiego brakuje jednolitego świata przedstawionego, nie ma w niej bowiem jednolitej wypowiedzi narratora, która by gwarantowała jednolitą i ciagłą narrację o zdarzeniach. Po prostu inna realność językowa, inna praktyka tekstowa złożyła się na polifoniczną koncepcję tekstu kształtowaną w dziełach Dostojewskiego, a inna u Buczkowskiego. Rekonstruowana koncepcja tekstu w utworach autora Kapieli $w$ Lucca, trzeba to powtórzyć, nie opiera się na wypowiedziach, ale na ich uprzedmiotowieniu w postaci cy ta tów, które składa, redaguje, komponuje w większą całość pisarz-redaktor: „dopiero płaszczyzna nadawcy jako sprawcy tego negatywnego obrazu podmiotu utworu może zapewnić nie budzące wątpliwości dowody jego jedności”39. Dopiero w takiej konstrukcji widzę sens pojęcia kolażu w zastosowaniu do późnych utworów Leopolda Buczkowskiego ${ }^{40}$.

Praktyka tekstowa Buczkowskiego, okazuje się, jest wyraźnie opozycyjna w stosunku do prozy realistycznej, której wybitny przykład stanowi właśnie proza Do-

B a c h t i n, Problem tekstu $w$ lingwistyce, filologii i innych naukach humanistycznych, s. 434-435.

Zob. Błażejewski, op. cit., s. 117.

L. Bu c zkowski, Kapiele w Lucca. Warszawa 1974, s. 16.

In dy k, op. cit., s. 54-55, 106-107, 127.

B a ch t in, Problem tekstu $w$ lingwistyce, filologii i innych naukach humanistycznych, s. 412.

Ny c z, Sylwy wspótczesne, s. 40.

Zob. Ny c z, Tekstowy świat. - Kar p ow ic z, op. cit. 
stojewskiego, analizowana przez Bachtina. Polifoniczna koncepcja tekstu (bez względu na to, jakie może przynosić interpretacje) jest koncepcją głosu i wypowiedzi ustnej, koncepcja Buczkowskiego opiera się na montażu cytatów (wypowiedzi uprzedmiotowionych) wskazujacych na podmiotowośc pisarza-redaktora, czyli bardziej reaktywuje autora niźli narratora. Pierwsza ma za wzór mowę, druga - pisanie. Buczkowski po prostu pisze i komponuje teksty.

Leopold Buczkowski wyraźnie mówi, że nie pisze powieści. W wywiadzie z 1968 r. dla „Kontrastów” stwierdził to jednoznacznie:

Krytycy mylą się, nazywając moje książki powieściami. To nie są powieści, to są studia. Chciałbym, aby czytelnicy, i nie tylko czytelnicy, o tym pamiętali, a wtedy uniknie się wielu nieporozumieńn ${ }^{41}$.

W recepcji Buczkowskiego ustaliła się terminologia kompromisowa, przywołująca pojęcie dokumentu dla nazywania utworów pisarza ${ }^{42}$. Wydaje się, że zapoczątkował ją Zygmunt Trziszka. Dokumentarność prozy Buczkowskiego wiązał on niejednolicie: raz z plebejską tradycją pierwszego języka, wypowiedzią ustną, którą autor ten miał odtwarzać w swych wczesnych utworach, czyli w zgodzie $z$ koncepcją Henryka Berezy, drugi raz z językiem pisanym, albowiem - jak zakładał - „Pisarze dwudziestego wieku zyskali pełna świadomość tego, że pisanie jest zestawianiem wielości zapisów, które uzyskały charakter dokumentów" 43 . Z taką interpretacją wiązał przekonanie, które zostało zresztą później uznane, że podstawową metodą twórczą, jaką posługiwał się Buczkowski, była poetyka kolażu, czyli „zestawiania własnych i cudzych tekstów na zasadzie kontrapunktu, mozaikowości i symultanizmu. W praktyce pisarskiej chodzi przeważnie o użycie różnych tekstów w formie cytatu" ${ }^{44}$. Inni badacze, ze względu na przedmiot swojego zainteresowania, łączyli dokumentaryzm Buczkowskiego $\mathrm{z}$ narracją i nie analizowali jego dojrzałych utworów ${ }^{45}$. W końcu, mimo pewnych różnic w rozumieniu dokumentaryzmu utworów Buczkowskiego, przyjęło się to pojęcie traktować jako podstawowe.

Analiza nienarracyjnej koncepcji tekstu, którą próbowałem tu zestawić z koncepcja polifoniczną, budowaną na fundamencie wypowiedzi ustnej, sugeruje, iż $\mathrm{w}$ tekstach Buczkowskiego następowało $\mathrm{w}$ istocie stopniowe uwalnianie wypowiedzi od wypowiadającego, albowiem, po pierwsze, jej przytaczanie (cytowanie) uprzedmiotawiało wypowiedź, po drugie, zmieniało jej porządek $z$ opartego na logice na-

Rozmowa z Buczkowskim (wersja autoryzowana w połowie kwietnia 1968 roku [...]). W zb.: ...zima bywa się pisarzem..., s. 186.

42 ski-Kres Kresów. W zb.: Kresy w literaturze. Twórcy dwudziestowieczni. Red. E. Czaplejewicz, E. Kasperski. Warszawa 1996. - Bu ryła, op. cit.

Ibidem, s. 96. Trziszka, jak się wydaje, inspirował się tu koncepcją R. Ny c za (O kolażu tekstowym. $\langle$ Na materiale prozy Leopolda Buczkowskiego〉. W zb.: Pogranicza i korespondencje sztuk. Studia. Red. T. Cieślikowska, J. Sławiński. Wrocław 1980).

Zob. Kasperski, op. cit. - Buryła, op. cit. 
stępstwa i rozwoju zdarzeń - opowieści - na porządek dowolnego następstwa, nie związanego już z jakimkolwiek tematem. Powoduje to, $z$ jednej strony, nowe możliwości konfrontacji pomiędzy różnymi cytatami lub częściami wypowiedzi-cytatu, jak to pokazuje dyskurs konwersacyjny Urody na czasie, a z drugiej strony - sens tekstu, kształtowany dotąd na poziomie wypowiedzi, zostaje przesunięty na poziom całego utworu, na poziom kompozycji zależnej od decyzji pisarza-redaktora i wytwórcy tekstu. Pisarz staje się wtedy performerem, a proces kształtowania tekstu literackiego przypomina proces performancji tworzacy performans, jak to wynika $z$ koncepcji teoretyków performatywności ${ }^{46}$.

Richard Bauman pisze:

Performans jest formą komunikacyjnego pokazu, w którym performer przyjmuje odpowiedzialność wobec publiczności za prezentację komunikacyjnej zręczności [virtuosity], ujawniającą sposób, w jaki akt twórczości słownej jest dokonywany, bez względu na dodatkowe funkcje, które ów akt może pełnićc ${ }^{47}$.

Trudność zestawiania jakichkolwiek pisanych utworów literackich $\mathrm{z}$ performansem polega na tym, że praktyka performatyczna zazwyczaj wiąże się $z$ twórczościa paraliteracka, $z$ widowiskiem, występem grup aktorskich, $z$ pokazem scenicznym lub ulicznym; literatury dotąd nie porównywano do tekstowego performansu $^{48}$, a $z$ taka praktyką mamy do czynienia w wypadku późnych utworów Buczkowskiego. Bauman dodaje: „pojęcie performansu może także oznaczać zdarzenie [tj. sytuacje - B. O.], w jakim performans lub inne formy komunikacyjnego pokazu zachodzą" ${ }^{49}$. Właśnie zdarzeniowość praktyki komponowania tekstu literackiego, którego „istota leży w dekontekstualizacji i rekontekstualizacji dyskursu” ${ }^{50}$, mogła pociagać autora Kapieli w Lucca i utworów następnych. W zdarzeniowości tekstów późnego Buczkowskiego kryła się, moim zdaniem, zarówno pokusa atrakcyjności oraz siły wyrazu praktyki, ujętej w niepowtarzalną sytuację jednostkowości tworzenia i pracy, wypowiadana przez pisarza wielokrotnie potrzeba „żywej prozy”, dokumentaryzmu, jak i jego negatywny stosunek do poetyki romansu, a także nieliczenie się $\mathrm{z}$ konwencjami recepcji, które prowadziło go do autarkii, co z przykrością stwierdzał Błażejewski ${ }^{51}$.

Swiadectwem zdarzeniowości tekstów dojrzałego Buczkowskiego była wreszcie ewidentna relacyjność jego tekstowych performansów. Przejawiała się ona najpierw w stałej praktyce charakteryzowania postaci, widocznej już w Czarnym potoku i Doryckim krużganku - kiedy osobę protagonisty opisuje nie narrator, ale postronne osoby, które zetknęły się $\mathrm{z}$ nią $\mathrm{w}$ różnych okolicznościach i w różnym czasie, i kiedy kształtowany wizerunek postaci nie jest ani jednoznaczny, ani jed-

Zob. J. Loxley, Performativity. London and New York 2007. - M. Carls on, Performans. Przeł. E. Kubikowska. Warszawa 2007. - E. Fis cher-Lichte, Estetyka performatywności. Przeł. M. B or ow ski, M. Sugi e ra. Kraków 2008.

R. B a u m a n, Performance. Hasło w: Routledge Encyclopedia of Narrative Theory. Ed. D. Herm a n, M. Jahn, M.-L. Ry a n. London and New York 2005, s. 420.

Przy okazji performatywności literackiej Fis cher-Lichte (op. cit., s. 25) wspomina o „powieściach labiryntach".

B a u ma n, op. cit., s. 420.

Ibidem.

Błażejew ski, op. cit., s. 138-148 (rozdz. Autarkia). 
nolity. Relacyjność przejawiała się również w „Z d e r z e n i a c h” wypowiedzi rozmawiających lub oceniających się ludzi w Urodzie na czasie. Bierze się to, jak już wspominałem, z przytaczania całych rozmów, konwersacji towarzyskich, kiedy uwolnione od sytuacyjnego kontekstu wypowiedzi przeniesione zostają do nowej, przypadkowej konfiguracji składniowej i nabierają tam innego, zaskakującego sensu. Podobnie dzieje się w przypadku szkicowania i figuracji mikroopowieści. Przykładem są Kapiele $w$ Lucca - tekst zarysowuje stale występujące wątki wojny, czarownictwa i satanizmu i konfrontuje ich zmieniajacy się sens. W nowym kontekście zmienia się także sens wojny. W Kapielach $w$ Lucca mamy do czynienia z kilkoma mikroopowieściami wojennymi, rejestrującymi zbiorową euforię i ekscytację, jaką u mieszkańców Wiednia, Sarajewa i Pragi wzbudziła wieść o wybuchu pierwszej wojny światowej.

podążyłem do Sarajewa. Miasto zastałem, jak tego należało się spodziewać, w stanie burzliwej ekscytacji - gardząc bólem pospolitym, wznoszącym nieznośne okrzyki - ale, co prawda, nie tylko z powodu udanego zamachu na arcyksięcia. Groźne wieści nadeszły z macedońskiej granicy. [...] Wiedeń znajduje się w stanie afektu. Do Pragi przybył pociag Czerwonego Krzyża, zaopatrzony we wszystkie przybory niezbędne na polu bitwy. Zarządzono nowy pobór, ażeby w razie potrzeby mieć pod ręką silne rezerwy 52 .

Czytamy dalej, jak euforia przeradza się w wojenne szaleństwo.

I oto pod wpływem nieoczekiwanego sąsiedztwa wątków konstatujemy, że z czarownictwem i satanizmem dzieje się podobnie. Te praktyki społeczne nagle $\mathrm{w}$ zetknięciu z powszechnym szaleństwem wojennym, obudzonym przez wypadki historyczne, ukazują swoje nowe oblicze.

Powiadają, że czarownica, sed sit ut sit, jakkolwiek bądź, jest ona czarownicą, i sądzą, że lada dzień będzie sądzona i stracona, za nią pójdą niektóre inne wielkogłowy, luterskiego sposobu myślenia. Przyaresztowano już i popalono profesorów, kandydatów prawa, pastorów, kanoników i wikariuszów, alumnów, którzy potem mieli być pastorami, niektórych organistów, jeden flecista, dwóch innych szukano, lecz uciekli. Kanclerz i jego żona oraz żona sekretarza tajnego już są straceni5 ${ }^{53}$.

Konfrontacja jednego szaleństwa $z$ drugim szaleństwem wzmacnia sugestię zbiorowego obłędu. A o to chodzi pisarzowi-performerowi.

Na tym, jak wiemy, nie wyczerpuje się sens Kapieli $w$ Lucca. W utworze, jak gdzie indziej mówi sam autor, są także inne wątki: „Kapiele $w$ Lucca to podręcznik łacińskości, wywodzimy się przecież z kultury śródziemnomorskiej”54. Zacytowany zostaje tam cały spis treści łacińskiego traktatu retorycznego, którego nie trzyma się jednak tekst utworu, gubiąc w istocie jego wskazania i regulacje ${ }^{55}$. Jest także czytelny w utworze wątek tytułowy. Jak wspomina Nycz, „Kapiele w Lucca przywołują tytuł utworu stanowiącego część Obrazów z podróży Heinego [...]"56. Dwukrotnie w tekście Buczkowskiego pojawia się nazwisko niemieckiego poety i dwa krótkie fragmenty, jakby wyrwane $z$ innego kontekstu, stylizowane na typową wolno-

Buczkows ki, Kapiele w Lucca, s. 164.

Ibidem, s. 175.

L. B u c zk ow s ki, Proza żywa. Bydgoszcz 1986, s. 32.

Zob. A. Gołąb, Zagadnienie spójności tekstu „Kapieli w Lucca” Leopolda Buczkowskiego. „Pamiętnik Literacki” 1979, z. 3.

Ny cz, Sylwy współczesne, s. 37. 
ściową opowieść, tak charakterystyczną dla Obrazów z podróży Heinricha Heinego, które w stosunku do poprzednich wątków zbiorowego szaleństwa pełnią wyraźną funkcję kontrapunktu:

W całej naturze tylko człowiek jest wolny i on jeden ma świadomość swej wolności. Wolność świadoma siebie, oto jest źródło pierwotne całego szeregu zjawisk, które przyjmują nazwę moralnych i stanowić będą dla człowieka sferę działalności nie znanej reszcie natury ${ }^{57}$.

Nieczytelność utworów Buczkowskiego, moim zdaniem, bierze się także z nieczytelności przedsięwzięcia, którego się podjął pisarz - ukształtowania nowej formacji tekstu literackiego, tekstowej performancji, do której jeszcze nie przywykł czytelnik. Buczkowski już nie opowiada anegdot, fabuł ani historii, polega wyłącznie na sprawności i wielomówności języka, na tekstach oraz cytatach. I w tym sensie, jak mówią filozofowie, nie przedstawia świata ${ }^{58}$. Wszystko nam komunikuje w dyskursywny sposób, dając do zrozumienia, że opisywane zjawiska maja jednak związek z naszym światem.

Nienarracyjność późnych utworów Buczkowskiego stawia problem komunikacji, tzn. w jaki sposób, za pomoca jakich środków przekazywać sens zdarzeń i zjawisk, o których się pisze w tekstach. W Urodzie na czasie autor wykorzystał konwersacyjny styl wymiany wypowiedzi, który imitując rozmowę na różne tematy, w różnych okolicznościach społecznych i historycznych, był otwarty na informowanie, polemikę i pastisz. W późniejszych utworach układ komunikacyjny wypowiadania i relacjonowania jeszcze się komplikuje. W Kapielach $w$ Lucca przeważa dyskurs, przybierający różne formy stylizacyjne i funkcjonalne, pojawiają się krótkie, powikłane tematycznie fragmenty narracji oraz często rozbudowywany metadyskurs autotematyczny, a zarazem filozoficzny. Dwa chyba tematy - zdarzenia i postaci sygnalizujące problemy kultury europejskiej (związane przede wszystkim z łacińskim rodowodem Europy, jak też z chrześcijaństwem) oraz zdarzenia i figury dowódców i żołnierzy z pierwszej wojny światowej - dominują w utworze, nadto toczy się tam metaliteracki spór między estetyką romansu a podejmowaną na wiele sposobów prozą wielorakiego widzenia.

[...] Rozamunda: wypędza kury z grządki i przypasuje ogrodnikowi miecz do boku, nakazując ruszać natychmiast do królewskiego powstania. Ogrodnik się sprzeciwia (powiada), że woli sadzić kapustę, niż zbierać wawrzyny. Precz, woła ona i wypędza go za drzwi. Za drzwi! (woła). Ten romans jest dziełem ogromnym, chociaż jeszcze nie skończony ${ }^{59}$.

Zauważmy, że podejmowane są różne kwestie, a całość dyskursu wydaje się

Buczkows ki, Kapiele $w$ Lucca, s. 181

Zob. J. Derrida, Pismo filozofii. Wybrał, przedmowa opatrzył B. Ban a siak. Wyd. 2. Kraków 1993. - B. B a n a siak, Destrukcja przedstawienia $w$ literaturze wspótczesnej. (Mallarmé Roussel). „Sztuka i Filozofia” 1993, nr 7. - I. Lor en c, Świadomość i obraz. Studia z filozofii przedstawienia. Warszawa 2001.

Buczkowski, Kapiele $w$ Lucca, s. 60. 
stylizowana i parodiowana. Jakkolwiek kształtuje się złożona sytuacja, to z cała wyrazistością zarysowuje się jej sztuczność, stylizowany, jakby przytoczony status. Można więc sądzić, że cytatowy charakter przekazu tekstowego tak charakterystyczny dla Urody na czasie ujawnia się również w Kapielach $w$ Lucca.

Innym sposobem tworzenia tekstu jest hybrydyzacja fragmentów - albo dotyczących rozmaitych wydarzeń, tematów czy problemów, albo relacjonowanych $z$ różnych punktów widzenia. Pozwolę sobie na przytoczenie dłuższego cytatu, pokazującego proces tekstowej jukstapozycji, tylko w tej bowiem formie staje się on widoczny.

Poszedłem szybko w przeciwnym kierunku. Wiedziałem wprawdzie, że w ten sposób nie dostanę się do Przemyśla, słyszałem, że żandarmi coś za mną wołali, ale nie odwracałem się. Kiedy przechodziłem w pobliżu fortu piątego, dostrzegłem patrol kozaków, ale natychmiast odjechali wyciągniętym galopem, a dwaj inni żandarmi zarzucili broń na ramiona i oddalili się brzegiem koniczyny pokosem leżącej. Przez mała chwilę wcale nie wiedziałem, co mam począć. W pierwszej chwili przez San, skąd przybyłem, wrócić z powrotem - nagle jednak przyszła mi myśl i wytężonym krokiem ruszyłem za żandarmami.

Chwała Bogu, powiedzieli ci postrzelani, skoro patrol zniknął już za drzewami. Podnieśli się ze swojej kryjówki, rozcierając zziębnięte ręce.

Gorączka z rany zaczyna już pana mocno atakować. Za dwie godziny nie będziesz się pan w stanie utrzymać na nogach. Poprowadzę pana. Nie, nie, nie! Wśród tak szlachetnych sporów doszli do wioski Żuratyn, przezornie jednak ominęli samą miejscowość i wybrali sobie daleki manowiec przez las i pole.

Rana moja jest bagatelką, i począł wyskakiwać, byle wrócić do żony. Spójrz tylko, jaki piękny wschód księżyca 60 .

Przytoczony fragment przedstawia różne mikroopowieści z rozmaitych narracji - w taki sposób, że ukazuje jednocześnie wielorakość zdarzeń i wielość narracji (punktów widzenia), a ponadto zadziwiającą biegłość głównego redaktora-układacza, który ujawnia swój ironiczny stosunek i wariacyjny kunszt pisarski. Widać zatem, że proces komunikacji między pisarzem a czytelnikiem nie ogranicza się tu wyłącznie do rozumienia tekstu, obejmuje także zrozumienie kompozycji całości, odrębności fragmentów, stylistycznej i gramatycznej zmienności oraz pragmatyczny stosunek nadawcy do przekazywanego tekstu. Wydaje się, że istota praktyki pisarskiej zaprezentowanej przez Buczkowskiego w późnych utworach jest k o m p o z yc ja właśnie, której podporządkowane zostają bardzo różne fragmenty bardzo różnych gatunków pisania - narracji i dyskursu. Dopiero na poziomie kompozycji ujawnia się perspektywa redaktora, performera i pisarza. To głównie pisanie i performancja tworza późne utwory Buczkowskiego.

Współcześnie praktykę performancji, czyli prezentacji występów, widowisk i happeningów, obejmuje się pojęciem performatywności i wiąże się zazwyczaj nie tyle $z$ przedstawianiem narracji, ile $z$ samym działaniem na podobieństwo performatywów Johna L. Austina lub aktów typowych dla filozoficznej szkoły analitycznej w określonej przestrzeni społecznej. Performans bowiem znosi granicę między sztuką a życiem, między fikcją a rzeczywistością ${ }^{61}$. Przypomnijmy, że wielokrotnie Buczkowski swoje utwory traktował zdecydowanie jako studia, dokumenty albo 
prozę żywą. Tę dokumentarną siłę jego dzieł upatrywałbym właśnie w performatycznej praktyce tekstowej pisarza, w pokazaniu sieci relacji i dekontekstualizacji rozmaitości mikrotekstów, komponowanych na użytek czytelnika w tekście-książce. Performatywność prozy autora Kamienia $w$ pieluszkach nie polega przecież na składnych i wiarygodnych opowieściach o kulturze i wojnie, ale na prezentacji i uruchomieniu nowych kontekstów dla cytatów mowy i gatunków pisania, które w licznych zderzeniach, poprzez dekontekstualizację słów, wyrażeń i dyskursów, ujawniają nowe sensy, uwalniają się od stereotypów, polemizują, ironizują, walczą i przekonują. Podlegaja procesowi, jak to określa Judith Butler - re si g n ifik ac j i ${ }^{62}$, czyli ułatwiaja demaskację, zafałszowanie i ceremonialność starych praktyk, a tym samym sprzyjają zwalczaniu duchowej opresji i zniewolenia.

O pierwszych praktykach performatywnych możemy mówić już w latach pięćdziesiątych XX wieku, o właściwej zaś sztuce performansu dopiero w latach siedemdziesiątych ${ }^{63}$. A wielu badaczy łączy współczesne praktyki performansu z filozofią postmodernizmu ${ }^{64}$. Również w opiniach polskich literaturoznawców zdarzaja się interpretacje wiążące utwory Buczkowskiego $z$ filozofią postmodernizmu ${ }^{65}$. Rzeczywiście, powierzchowne zestawienia tekstowych performansów z postmodernistycznymi praktykami w sztuce i literaturze moga prowadzić do tego rodzaju spostrzeżeń, jednakże przy głębszej analizie takie hipotezy okazują się mylące. Łacczyłbym zdecydowanie eksperymentatorstwo Buczkowskiego z projektami i koncepcjami polskiej i międzynarodowej awangardy ${ }^{66}$.

Z koncepcja tekstowego performansu wiąże się jeszcze jedna kwestia. Jak stwierdził Bauman - w praktykach performatywnych trzeba brać pod uwage znaczacy udział publiczności i traktować go jako integralny składnik w interakcyjnym układzie komunikacyjnym między twórcą a odbiorcą ${ }^{67}$. Proza Buczkowskiego, paradoksalnie, wymaga nadzwyczajnej współpracy czytelnika. Kompozycyjna aktywność autora-redaktora, prowadząca do układów notorycznie heterogenicznych i nieciągłych przytoczeń, stylizacji i metadyskursów, tworzy szczególne warunki utrudnionej lektury ukształtowanych w ten sposób utworów. Nierzadka jest tedy sytuacja, kiedy czytelnik dostrzega, że „przyjemność tekstu nie jest pewna”68, kiedy ciekawość lektury graniczy ze znużeniem czy wręcz z rezygnacją. Autor Oficera na nieszporach jest znacznie bliższy w komponowaniu tekstów awangardowej praktyce teatralnej oraz literackiej, która nie angażuje widza i czytelnika w empatyczne przeżywanie zdarzeń, wczuwanie się w postępowanie postaci, ale - jak pisze

J. Butler, Walczace słowa. Mowa nienawiści i polityka performatywu. Przeł. A. Ostolski. Warszawa 2010, s. 180-188. Zob. też L oxley, op. cit., s. 127.

Zob. C a rls o n, op. cit., s. 162.

Zob. ibidem, s. 203-204.

Zob. np. M. D ą b row s ki, Postmodernizm: myśl i tekst. Kraków 2000, s. 102-111.

Zob. N. F. Č uža k, Literatura fakta. Nachdruk der Ausgabe: Moskau 1929, mit einer Einleitung von H. Günter. München 1972. - A. Turowski, Konstruktywizm polski. Próba rekonstrukcji nurtu (1921-1934). Wrocław 1981. - S. R. Le e, Trudne przymierze. Polska awangarda poetycka $w$ kręgu idei lewicy (1918-1939). Warszawa 1982. - Ka r p o w i c z, op. cit.

B a u m a n, op. cit., s. 420.

R. B arthes, Przyjemność tekstu. Przeł. A. Lew ań s ka. Warszawa 1997, s. 88. 
Walter Benjamin - „winna raczej dziwić się stosunkom, w których żyje”69. Awangardowa praktyka tekstów, w której Buczkowski posługuje się dezautomatyzacja rozumienia problemu, efektami obcości, dekontekstualizacją, przypomina raczej Bertolta Brechta, a znacznie mniej koncepcje estetyki performatywności, jakie zdają się budować teoretycy nowoczesnego performansu parateatralnego wokół na nowo interpretowanego pojęcia katharsis ${ }^{70}$. Niearystotelesowska interpretacja literatury, z jaką styka się nieuchronnie czytelnik późnych utworów Buczkowskiego, nie pomaga w doświadczaniu „przyjemności tekstu”, ponieważ odbiorcy trudniej przekonać się, że autor Kamienia $w$ pieluszkach, jak pisze Falkiewicz, to „jeden z największych artystów słowa w języku polskim, człowiek posiadający słuch absolutny słowa, umiejący napisać wszystko"71. A tak właśnie jest.

Abstract

BOGDAN OWCZAREK University of Warsaw

\section{ON SOME IDEAS IMPORTANT FOR UNDERSTANDING LEOPOLD BUCZKOWSKI'S PROSE}

The article presents some ideas which the author has formulated within long-standing studies of Leopold Buczkowski's prose. They can be listed in the following order: 1) Buczkowski's prose is not a uniform collection of texts - contrary to that, under careful scrutiny it is viewed as a multiform conglomerate of texts; legibility of Czarny potok (Black Torrent) tells little about that of Uroda na czasie (A Fashionable Beauty) (the meaning of "legibility" in Buczkowski's prose analysis is quite imprecise); 2) his late creativity (from Uroda na czasie 〈A Fashionable Beauty) takes up a n o n- na r r a tiv e mode of writing which no longer relies on telling the history and fortune of characters but rather 3) matching real and stylised quotations, Buczkowski juxtaposes pieces of conversations, discourses and micronarrations to exploit the senses and surprising meanings hidden in them. At the same time he builds textual performances which in the new contexts gain new performative meanings.

W. B e nj a mi in, Co to jest teatr epicki? Przeł. K. Krze mi e ń. „Miesięcznik Literacki” 1976, nr 6. Zob. Fis cher-Lichte, op. cit., s. 305-306.

Falkiewicz, op. cit., s. 155. 